\title{
The supply of choline is important for fetal progenitor cells
}

\author{
Steven H. Zeisel, M.D., Ph.D. ${ }^{1}$ [Professor of Nutrition and Pediatrics] \\ Nutrition Research Institute, School of Public Health and School of Medicine, The University of \\ North Carolina at Chapel Hill, Kannapolis, NC 28081
}

\begin{abstract}
Fetal progenitor cells proliferate, migrate, differentiate and undergo apoptosis at specific times during fetal development. Choline is needed by these cells for membrane synthesis and for methylation. There is growing evidence that this nutrient also modulates epigenetic regulation of gene expression in both neuronal and endothelial progenitor cells, thereby modifying brain development. It is likely that these mechanisms explain why, in rodent models, maternal dietary intake of choline influences both angiogenesis and neurogenesis in fetal hippocampus, and results in life-long changes in memory function. This also may explain why women eating diets low in choline have a greater risk of having a baby with a birth defect. Choline is mainly found in foods that contain fat and cholesterol, and intake of such foods has diminished in response dietary advice from nutritionists and physicians. Forty years ago, diets commonly contained choline-rich foods but now women in the USA tend to eat diets low in choline content. Premenopausal women normally may require less choline in their diet than do men and postmenopausal women, because estrogen induces the gene for the enzyme catalyzing endogenous biosynthesis of the cholinecontaining phospholipid phosphatidylcholine. However, many women have a single nucleotide polymorphism (SNP) that blocks the induction of endogenous biosynthesis, thereby making them require more dietary choline. When these women eat diets low in choline, the supply of this nutrient to the fetus is likely to be inadequate, and may perturb progenitor cell proliferation, migration, differentiation and apoptosis.
\end{abstract}

\section{Choline and fetal progenitor cells}

During embryogenesis, progenitors of neurons and blood vessels proliferate, differentiate, many migrate to new locations, and some of these cells die by apoptosis [1-3]. Choline is an important nutrient that influences all of these processes in neural and endothelial progenitor cells. It is possible that choline exerts these effects by altering membranes (is it a component of the membrane phospholipids phosphatidylcholine and sphingomyelin) or by altering neurotransmission (it is a precursor for the neurotransmitter acetylcholine) [4]. However, there is growing evidence that the mechanisms mediating these effects are epigenetic, and depend on choline's role as a methyl donor [5].

When pregnant rats or mice are fed diets in which the choline content is manipulated, there are marked changes within progenitor cells (neural and endothelial) of the developing

\footnotetext{
(c) 2011 Elsevier Ltd. All rights reserved

Direct correspondence to: Steven H. Zeisel, Professor of Nutrition and Pediatrics, Nutrition Research Institute, School of Public Health and School of Medicine, The University of North Carolina at Chapel Hill Kannapolis, NC 28081 phone (704) 250-5003 fax (704) 250-5001 steven_zeisel@unc.edu.

${ }^{1}$ Dr. Zeisel has no conflicts of interest; he serves on scientific advisory boards for Hershey, Glaxo Smith Kline, Solae and Dupont.

Publisher's Disclaimer: This is a PDF file of an unedited manuscript that has been accepted for publication. As a service to our customers we are providing this early version of the manuscript. The manuscript will undergo copyediting, typesetting, and review of the resulting proof before it is published in its final citable form. Please note that during the production process errors may be discovered which could affect the content, and all legal disclaimers that apply to the journal pertain.
} 
hippocampus. In rodent models, maternal diets low in choline during days 12-17 of pregnancy result half as much mitosis in neural progenitor cells in the subventricular zone of the fetal hippocampus when compared to a higher choline diet [6-8]. Low choline was associated with increased expression of genes which inhibit cell cycling (CDKN3; p15Ink4B; p27Kip1) in the neural progenitor cells of the fetal hippocampus [9, 10]. Also, lower choline was associated with increased expression of genes and proteins that mark the differentiation of progenitor cells into mature neurons (calretinin, TOAD) [6, 11-13]. Lower choline decreased the expression of proteins that drive neuronal migration (netrin) and decreased the rate at which neuronal precursor cells in the subventricular region migrated to the dentate gyrus region of the hippocampus after undergoing mitosis [6-8, 14]. Finally, lower choline increased the rates of apoptosis in fetal neuronal progenitor cells $[6-8,15,16]$. These responses are similar for studies of fetal brains from dams consuming differing amounts of choline in diet and for studies of neural progenitor cells in culture (with medium choline concentrations being varied from $5 \mu \mathrm{M}$ to $280 \mu \mathrm{M}$, with control medium being 70 $\mu \mathrm{M}$ (similar to brain tissue choline concentrations) [5, 17].

Neural progenitor cells are not alone in their responsiveness to available choline; similar effects were observed for endothelial progenitor cells in the fetal hippocampus [18]. Compared to higher choline, a maternal diet low in choline during days 12-17 of gestation in the mouse decreased mitosis of endothelial progenitor cells by $32 \%$ in fetal hippocampus. At the same time differentiation of these cells (as measured by cells expressing factor VIII related antigen) increased by $25 \%$ [18]. These changes were associated with $>25 \%$ decrease in the number of blood vessels in fetal hippocampus when dams ate diets low in choline compared to high [18]. Expression of genes for the angiogenic signals derived from both endothelial and neuronal progenitor cells was increased in the low choline fetal hippocampus (VEGF C (Vegfc), 2.0-fold, and angiopoietin 2 (Angpt2), 2.1-fold) [18]; these angiogenesis signals accelerate differentiation and decrease the available period for proliferation.

These changes in neurogenesis and angiogenesis are likely important modulators of later brain function. A maternal diet high in choline during days 12-17 of gestation in the rat enhanced long term potentiation (LTP) in the offspring when they were adult animals [19$21]$ and enhanced visuospatial and auditory memory by as much as $30 \%$ in the offspring throughout their lifetimes [22-28]. Indeed, adult rodents decrement in memory as they age, and offspring exposed to extra choline in utero did not show this decrement in memory [24, 27]. Also, choline exposure, in utero, attenuated age-related declines in exploratory behavior [29]. There was a dose response to choline; mothers fed choline deficient diets during late pregnancy had offspring with insensitivity to LTP when they were adult animals [19], and decremented visuospatial and auditory memory [26]. The effects of choline supplementation in utero are seen in other model systems studied by a variety of different research teams. Supplementation with choline attenuated behavioral alterations but not motor abnormalities associated with fetal alcohol exposure in rodents [30-32]. In a mouse model (Mecp2(1lox) knockout) for Rett syndrome, the second most common cause of mental retardation in girls, choline supplementation in utero reduced some of the anatomical and behavioral deficits in mutant mice [33, 34].

\section{Epigenetic mechanisms for choline's effects on fetal progenitor cells}

Choline is a major source of methyl groups needed for methylation of DNA and histones (these are the predominant epigenetic marks that influence gene expression during development) [35]. The metabolism of choline, folate, vitamin B12, vitamin B6 and methionine are interrelated and disturbances in one of these metabolic pathways are associated with compensatory changes in the others. This means the methyl-groups from 
methyltetrahydrofolate (MTHF), methionine and choline can be interchangeable. For example, methionine can be formed via two pathways: from homocysteine using methylgroups donated by MTHF [36], or from methyl-groups donated by betaine (derived from choline) [37]. MTHF can be formed from one-carbon units derived from serine or from the methyl-groups of choline through dimethylglycine [38]. Finally, choline can be formed from methyl-groups derived from $S$-adenosylmethionine (AdoMet) [39]. When animals and humans are fed a diet deficient in choline, dietary folate requirements increase [40, 41]. Alternatively, if they are fed a diet deficient in folate, dietary choline requirements increase as choline becomes the primary methyl group donor [42-44].

DNA methylation occurs at cytosine bases that are followed by a guanosine (5'-CpG-3' sites) [45]. In mammals, most CpG sites in DNA are methylated (90-98\%; [46]), but there are specific CpG-rich areas of DNA where most CpGs are not methylated; these are called $\mathrm{CpG}$ islands [47]. When these $\mathrm{CpG}$ islands are methylated, gene expression is usually suppressed or silenced $[47,48]$. The pattern of DNA methylation in CpG islands varies by tissue type, and likely accounts for why genes are expressed differentially between tissues [46]. In addition, epigenetic marks on chromatin proteins (histones) regulate DNA expression [4951]. Simplistically, histones are tightly wound around DNA and prevent access to transcription factors. When modified by epigenetic marks, these proteins loosen up and create gaps through which transcription factors can pass. Epigenetic marks on DNA and on histones communicate with each other. Once methyl-CpG binding proteins attach to methylated cytosines, they attract a variety of other proteins, some of which have enzymatic activity that can further modify neighboring histones by methylating or acetylating specific amino acid residues [52]. This reinforces the signals that suppress gene expression.

The DNA and histone methyltransferases all use $S$-adenosylmethionine (AdoMet) as the methyl donor. The availability of AdoMet is directly influenced by diet as AdoMet is formed from methyl-groups derived from choline, methionine, or methyl-tetrahydrofolate. Thus, it is to be expected that diet during pregnancy influences the epigenetic status of the developing fetal brain. A maternal diet low in choline during pregnancy days 11-18 changed in epigenetic marks present in rodent fetal brain [10, 18]. Global DNA methylation was decreased in the neuroepithelial layer of the hippocampus in fetal brains, and specifically, the gene encoding cyclin-dependent kinase $(C d k n 3)$ was hypo-methylated in its promoter $[10,53]$. This hypomethylation resulted in increased gene expression and increased downstream signaling that resulted in decreased cell cycling [10], consistent with decreased neurogenesis. Similarly, genes regulating angiogenesis were hypomethylated (cytosinephosphate-guanine dinucleotide islands in the proximity of the promoter areas of Vegfc and Angpt2) and these genes were over expressed, resulting in more rapid differentiation with decreased cell proliferation, and thereby decreased number of blood vessels in fetal brain [18].

Choline also influences the methylation of histones. In the mouse model discussed earlier, where the pregnant dam had low (versus high) choline during gestational days 12-17 there was altered methylation of the histone $\mathrm{H} 3$ in fetal hippocampi [5]. In the ventricular and subventricular zones, monomethyl-lysine 9 of $\mathrm{H} 3$ (H3K9me1) was decreased by $25 \%$ and in the pyramidal layer, dimethyl-lysine 9 of histone $\mathrm{H} 3$ (H3K9me2) was decreased by $37 \%$. The same effects of low choline on $\mathrm{H} 3$ methylation were observed in neural progenitor cells (embryonic day 14) in cell culture. Gene expression of G9a histone methyltransferase was decreased by $80 \%$ in low choline fetal hippocampus and may explain this observation. These histone changes have functional significance as histone $\mathrm{H} 3$ was hypomethylated upstream of the RE1 binding site in the calbindin 1 promoter; REST binding to RE1 (recruits G9a histone methyltransferase) was decreased by $45 \%$ in low choline. These changes resulted in increased expression of calbindin 1 in the low choline fetal hippocampi 
(by 260\%). Thus, CD modulates histone methylation in neural progenitor cells, and this could underlie the observed changes in neurogenesis [5].

\section{Is there reason for concern about dietary choline in pregnant women?}

Aside from diet, new choline molecules can only be derived from de novo synthesis of phosphatidylcholine that is catalyzed by phosphatidylethanolamine-N-methyltransferase (PEMT; catalyzes the methylation of phosphatidylethanolamine to phosphatidylcholine) [39]. Many foods contain choline or choline-containing compounds [54, 55], these include eggs, beef, chicken, fish and milk as well as wheat germ and certain beans [56]. See also http://www.nal.usda.gov/fnic/foodcomp/Data/Choline/Choline.html. The National Health and Nutrition Examination Survey of food intake in the USA found that only a small portion of Americans in all age groups ate diets achieving the recommended intake for choline [63].

Women are designed to produce more choline during the period when they need it to build a fetus. In adult men and postmenopausal women, dietary choline deficiency leads to liver dysfunction and muscle damage; however, less than half of premenopausal women develop organ dysfunction when deprived of choline [64]. The capacity to form new choline molecules depends on de novo synthesis of PtdCho that is catalyzed by phosphatidylethanolamine-N-methyltransferase [39]. The gene for this enzyme (PEMT) is induced by estrogen [65], and maximal induction is achieved at concentrations of estrogen that are normally seen in pregnant women. A significant portion of women have a single nucleotide polymorphism (SNP) in this gene (PEMT rs12325817) and in postmenopausal women one variant allele is sufficient to increase the risk of developing choline deficiencyinduced organ dysfunction by 25 -fold [64, 66, 67]. This SNP prevents estrogen from inducing PEMT activity [65], and young women who are homozygous for this SNP all require dietary sources of choline [64]. Three quarters of women in Chapel Hill, NC have one variant allele for this SNP, and almost a quarter of women have two variant alleles.

There are other SNPs that have a profound impact on choline requirements [66, 67]. Premenopausal women who are carriers of the very common 5,10methylenetetrahydrofolate dehydrogenase SNP (MTHFD1; rs2236225) are more than 15 times as likely as non-carriers to develop choline deficiency-induced organ dysfunction [67].

Pregnancy and lactation are times when demand for choline is especially high because transport of choline from mother to fetus depletes maternal choline stores [68, 69]. As noted earlier, women with estrogen have increase capacity to form choline molecules via PEMT activity. In addition, multiple mechanisms exist that enhance delivery of choline from mother to the fetus and infant. In mammals, the placenta delivers choline to the fetus by pumping it against a concentration gradient [70]. Choline concentration in amniotic fluid is 14-fold higher than in maternal blood [71]. The mammary gland extracts choline from maternal blood, synthesizes important choline metabolites, and secretes all of these into milk [72-75]. Choline concentrations in the plasma or serum of human infants are elevated during the perinatal period (compared to adults) and slowly decrease after birth until they reach adult levels sometime after the first year of life [71, 76-78]. Presumably these very high levels ensure enhanced availability of choline to the developing tissues.

\section{Birth defects and choline}

Adequate dietary folate intake by mother during pregnancy can prevent $50 \%$ or more of neural tube defects (NTDs) in babies [79, 80]. As discussed earlier, choline and folate metabolism are highly interrelated. Inhibition of choline uptake and metabolism is associated with the development of NTDs in mice [81, 82]. Women vary enough in dietary choline intake to influence the risk that they will have a baby with a birth defect; at least 
$25 \%$ of women eat so little choline that their pregnancies are at risk of having a baby with a birth defect $[60,83,84]$. A retrospective case-control study (400 cases and 400 controls) of periconceptional dietary intakes of choline in women in California found that women in the lowest quartile for daily dietary choline intake had 4 times the risk of having a baby with an NTD than did women in the highest quartile for intake [60]. Elevated NTD risk was also associated with lower concentrations of serum total choline in a folate-fortified population [85]. Additional birth defects that have been associated with low dietary intake of choline include cleft lip and orofacial defects [83].

\section{Summary}

Choline appears to have an important role in modulating mitosis, apoptosis, differentiation and migration of neural and endothelial progenitor cells. These effects, likely mediated via epigenetic mechanisms, may also apply to other forms of progenitor cells. Humans need this nutrient, and there is significant variation in the dietary requirement, such that some pregnant women may need to ingest much more choline than do others.

\section{Acknowledgments}

This work was funded by grants from the National Institutes of Health (DK55865). Support for this work was also provided by grants from the NIH to the UNC Nutrition \& Obesity Research Center (DK56350).

\section{References}

[1]. Oppenheim RW. Cell death during the development of the nervous system. Ann Rev Neurosci. 1991; 14:453-501. [PubMed: 2031577]

[2]. Thompson CB. Apoptosis in the pathogenesis and treatment of disease. Science. 1995; 267:145662. [PubMed: 7878464]

[3]. Merry D, Korsmeyer S. Bcl-2 gene family in the nervous system. Annu Rev Neurosci. 1997; 20:245-67. [PubMed: 9056714]

[4]. Zeisel SH. Choline: critical role during fetal development and dietary requirements in adults. Annu Rev Nutr. 2006; 26:229-50. [PubMed: 16848706]

[5]. Mehedint MG, Niculescu MD, Craciunescu CN, Zeisel SH. Choline deficiency alters global histone methylation and epigenetic marking at the Re1 site of the calbindin 1 gene. Faseb J. 2010; 24:184-95. [PubMed: 19752176]

[6]. Albright CD, Friedrich CB, Brown EC, Mar MH, Zeisel SH. Maternal dietary choline availability alters mitosis, apoptosis and the localization of TOAD-64 protein in the developing fetal rat septum. Brain Res. 1999; 115:123-9.

[7]. Albright CD, Tsai AY, Friedrich CB, Mar MH, Zeisel SH. Choline availability alters embryonic development of the hippocampus and septum in the rat. Brain Res. 1999; 113:13-20.

[8]. Craciunescu CN, Albright CD, Mar MH, Song J, Zeisel SH. Choline availability during embryonic development alters progenitor cell mitosis in developing mouse hippocampus. J Nutr. 2003; 133:3614-8. [PubMed: 14608083]

[9]. Albright CD, Mar MH, Friedrich CB, Brown EC, Zeisel SH. Maternal choline availability alters the localization of p15Ink4B and p27Kip1 cyclin-dependent kinase inhibitors in the developing fetal rat brain hippocampus. Dev Neurosci. 2001; 23:100-6. [PubMed: 11509832]

[10]. Niculescu MD, Craciunescu CN, Zeisel SH. Dietary choline deficiency alters global and genespecific DNA methylation in the developing hippocampus of mouse fetal brains. Faseb J. 2006; 20:43-9. [PubMed: 16394266]

[11]. Adams KM, Kohlmeier M, Powell M, Zeisel SH. Nutrition in medicine: nutrition education for medical students and residents. Nutr Clin Pract. 2010; 25:471-80. [PubMed: 20962306]

[12]. Albright CD, Siwek DF, Craciunescu CN, Mar MH, Kowall NW, Williams CL, et al. Choline availability during embryonic development alters the localization of calretinin in developing and aging mouse hippocampus. Nutr Neurosci. 2003; 6:129-34. [PubMed: 12722989] 
[13]. Albright CD, Tsai AY, Mar M-H, Zeisel SH. Choline availability modulates the expression of TGFß1 and cytoskeletal proteins in the hippocampus of developing rat brain. Neurochem Res. 1998; 23:751-8. [PubMed: 9566615]

[14]. Albright CD, Mar MH, Craciunescu CN, Song J, Zeisel SH. Maternal dietary choline availability alters the balance of netrin-1 and DCC neuronal migration proteins in fetal mouse brain hippocampus. Brain Res Dev Brain Res. 2005; 159:149-54.

[15]. Holmes-McNary MQ, Loy R, Mar M-H, Albright CD, Zeisel SH. Apoptosis is induced by choline deficiency in fetal brain and in PC12 cells. Devel Brain Res. 1997; 101:9-16. [PubMed: 9263575]

[16]. Yen CL, Mar MH, Meeker RB, Fernandes A, Zeisel SH. Choline deficiency induces apoptosis in primary cultures of fetal neurons. FASEB J. 2001; 15:1704-10. [PubMed: 11481217]

[17]. Niculescu MD, Craciunescu CN, Zeisel SH. Gene expression profiling of choline-deprived neural precursor cells isolated from mouse brain. Brain Res. 2005; 134:309-22.

[18]. Mehedint MG, Craciunescu CN, Zeisel SH. Maternal dietary choline deficiency alters angiogenesis in fetal mouse hippocampus. Proc Natl Acad Sci U S A. 2010; 107:12834-9. [PubMed: 20624989]

[19]. Jones JP, Meck W, Williams CL, Wilson WA, Swartzwelder HS. Choline availability to the developing rat fetus alters adult hippocampal long-term potentiation. Brain Res. 1999; 118:159_ 67.

[20]. Pyapali G, Turner D, Williams C, Meck W, Swartzwelder HS. Prenatal choline supplementation decreases the threshold for induction of long-term potentiation in young adult rats. $J$ Neurophysiol. 1998; 79:1790-6. [PubMed: 9535948]

[21]. Montoya DA, White AM, Williams CL, Blusztajn JK, Meck WH, Swartzwelder HS. Prenatal choline exposure alters hippocampal responsiveness to cholinergic stimulation in adulthood. Brain Res Dev Brain Res. 2000; 123:25-32.

[22]. Meck W, Williams C. Perinatal choline supplementation increases the threshold for chunking in spatial memory. Neuroreport. 1997; 8:3053-9. [PubMed: 9331913]

[23]. Meck W, Williams C. Characterization of the facilitative effects of perinatal choline supplementation on timing and temporal memory. Neuroreport. 1997; 8:2831-5. [PubMed: 9376513]

[24]. Meck W, Williams C. Simultaneous temporal processing is sensitive to prenatal choline availability in mature and aged rats. Neuroreport. 1997; 8:3045-51. [PubMed: 9331912]

[25]. Meck WH, Smith RA, Williams CL. Pre- and postnatal choline supplementation produces longterm facilitation of spatial memory. Dev Psychobiol. 1988; 21:339-53. [PubMed: 3378679]

[26]. Meck WH, Williams CL. Choline supplementation during prenatal development reduces proactive interference in spatial memory. Brain Res. 1999; 118:51-9.

[27]. Meck WH, Williams CL. Metabolic imprinting of choline by its availability during gestation: implications for memory and attentional processing across the lifespan. Neuroscience and biobehavioral reviews. 2003; 27:385-99. [PubMed: 12946691]

[28]. Williams CL, Meck WH, Heyer DD, Loy R. Hypertrophy of basal forebrain neurons and enhanced visuospatial memory in perinatally choline-supplemented rats. Brain Res. 1998; 794:225-38. [PubMed: 9622639]

[29]. Glenn MJ, Kirby ED, Gibson EM, Wong-Goodrich SJ, Mellott TJ, Blusztajn JK, et al. Agerelated declines in exploratory behavior and markers of hippocampal plasticity are attenuated by prenatal choline supplementation in rats. Brain Res. 2008; 1237:110-23. [PubMed: 18786518]

[30]. Thomas JD, Biane JS, O'Bryan KA, O'Neill TM, Dominguez HD. Choline supplementation following third-trimester-equivalent alcohol exposure attenuates behavioral alterations in rats. Behavioral neuroscience. 2007; 121:120-30. [PubMed: 17324056]

[31]. Thomas JD, Garrison M, O'Neill TM. Perinatal choline supplementation attenuates behavioral alterations associated with neonatal alcohol exposure in rats. Neurotoxicol Teratol. 2004; 26:3545. [PubMed: 15001212]

[32]. Thomas JD, O'Neill TM, Dominguez HD. Perinatal choline supplementation does not mitigate motor coordination deficits associated with neonatal alcohol exposure in rats. Neurotoxicol Teratol. 2004; 26:223-9. [PubMed: 15019955] 
[33]. Ward BC, Agarwal S, Wang K, Berger-Sweeney J, Kolodny NH. Longitudinal brain MRI study in a mouse model of Rett Syndrome and the effects of choline. Neurobiology of disease. 2008; 31:110-9. [PubMed: 18571096]

[34]. Nag N, Ward B, Berger-Sweeney JE. Nutritional factors in a mouse model of Rett syndrome. Neuroscience and biobehavioral reviews. 2008

[35]. Zeisel SH. Epigenetic mechanisms for nutrition determinants of later health outcomes. Am J Clin Nutr. 2009; 89:1488S-93S. [PubMed: 19261726]

[36]. Finkelstein JD. Pathways and regulation of homocysteine metabolism in mammals. Semin Thromb Hemost. 2000; 26:219-25. [PubMed: 11011839]

[37]. Park EI, Garrow TA. Interaction between dietary methionine and methyl donor intake on rat liver betaine-homocysteine methyltransferase gene expression and organization of the human gene. J Biol Chem. 1999; 274:7816-24. [PubMed: 10075673]

[38]. Gregory JF 3rd, Cuskelly GJ, Shane B, Toth JP, Baumgartner TG, Stacpoole PW. Primed, constant infusion with [2H3]serine allows in vivo kinetic measurement of serine turnover, homocysteine remethylation, and transsulfuration processes in human one-carbon metabolism. Am J Clin Nutr. 2000; 72:1535-41. [PubMed: 11101483]

[39]. Vance DE, Walkey CJ, Cui Z. Phosphatidylethanolamine N-methyltransferase from liver. Biochimica et biophysica acta. 1997; 1348:142-50. [PubMed: 9370326]

[40]. Selhub J, Seyoum E, Pomfret EA, Zeisel SH. Effects of choline deficiency and methotrexate treatment upon liver folate content and distribution. Cancer Res. 1991; 51:16-21. [PubMed: 1988081]

[41]. Varela-Moreiras G, Selhub J, da Costa K, Zeisel SH. Effect of chronic choline deficiency in rats on liver folate content and distribution. J Nutr Biochem. 1992; 3:519-22.

[42]. Jacob R, Jenden D, Okoji R, Allman M, Swendseid M. Choline status of men and women is decreased by low dietary folate. FASEB J. 1998; 12:A512.

[43]. Jacob RA, Jenden DJ, Allman-Farinelli MA, Swendseid ME. Folate nutriture alters choline status of women and men fed low choline diets. J Nutr. 1999; 129:712-7. [PubMed: 10082779]

[44]. Kim Y-I, Miller JW, da Costa K-A, Nadeau M, Smith D, Selhub J, et al. Folate deficiency causes secondary depletion of choline and phosphocholine in liver. J Nutr. 1995; 124:2197-203. [PubMed: 7965204]

[45]. Holliday R, Grigg GW. DNA methylation and mutation. Mutation research. 1993; 285:61-7. [PubMed: 7678134]

[46]. Suzuki MM, Bird A. DNA methylation landscapes: provocative insights from epigenomics. Nat Rev Genet. 2008; 9:465-76. [PubMed: 18463664]

[47]. Jeltsch A. Beyond Watson and Crick: DNA Methylation and Molecular Enzymology of DNA Methyltransferases. Chembiochem. 2002; 3:382.

[48]. Bird AP. CpG-rich islands and the function of DNA methylation. Nature. 1986; 321:209-13. [PubMed: 2423876]

[49]. Felsenfeld G, Groudine M. Controlling the double helix. Nature. 2003; 421:448-53. [PubMed: 12540921]

[50]. Esteve PO, Chin HG, Smallwood A, Feehery GR, Gangisetty O, Karpf AR, et al. Direct interaction between DNMT1 and G9a coordinates DNA and histone methylation during replication. Genes Dev. 2006; 20:3089-103. [PubMed: 17085482]

[51]. Quina AS, Buschbeck M, Di Croce L. Chromatin structure and epigenetics. Biochem Pharmacol. 2006

[52]. Clouaire T, Stancheva I. Methyl-CpG binding proteins: specialized transcriptional repressors or structural components of chromatin? Cell Mol Life Sci. 2008; 65:1509-22. [PubMed: 18322651]

[53]. Niculescu MD, Yamamuro Y, Zeisel SH. Choline availability modulates human neuroblastoma cell proliferation and alters the methylation of the promoter region of the cyclin-dependent kinase inhibitor 3 gene. J Neurochem. 2004; 89:1252-9. [PubMed: 15147518]

[54]. Zeisel SH, Mar MH, Howe JC, Holden JM. Concentrations of choline-containing compounds and betaine in common foods. J Nutr. 2003; 133:1302-7. [PubMed: 12730414] 
[55]. Zeisel SH, Mar M-H, Howe JC, Holden JM. Erratum: Concentrations of choline-containing compounds and betaine in common foods J. Nutr. 133: 1302-1307. J Nutr. 2003; 133:2918-9.

[56]. Caudill MA. Pre- and postnatal health: evidence of increased choline needs. J Am Diet Assoc. 2010; 110:1198-206. [PubMed: 20656095]

[57]. Fischer LM, Scearce JA, Mar MH, Patel JR, Blanchard RT, Macintosh BA, et al. Ad libitum choline intake in healthy individuals meets or exceeds the proposed adequate intake level. J Nutr. 2005; 135:826-9. [PubMed: 15795442]

[58]. Xu X, Gammon MD, Zeisel SH, Bradshaw PT, Wetmur JG, Teitelbaum SL, et al. High intakes of choline and betaine reduce breast cancer mortality in a population-based study. Faseb J. 2009; 23:4022-8. [PubMed: 19635752]

[59]. Bidulescu A, Chambless LE, Siega-Riz AM, Zeisel SH, Heiss G. Usual choline and betaine dietary intake and incident coronary heart disease: the Atherosclerosis Risk in Communities (ARIC) study. BMC cardiovascular disorders. 2007; 7:20. [PubMed: 17629908]

[60]. Shaw GM, Carmichael SL, Yang W, Selvin S, Schaffer DM. Periconceptional dietary intake of choline and betaine and neural tube defects in offspring. Am J Epidemiol. 2004; 160:102-9. [PubMed: 15234930]

[61]. Cho E, Zeisel SH, Jacques P, Selhub J, Dougherty L, Colditz GA, et al. Dietary choline and betaine assessed by food-frequency questionnaire in relation to plasma total homocysteine concentration in the Framingham Offspring Study. Am J Clin Nutr. 2006; 83:905-11. [PubMed: 16600945]

[62]. Konstantinova SV, Tell GS, Vollset SE, Ulvik A, Drevon CA, Ueland PM. Dietary patterns, food groups, and nutrients as predictors of plasma choline and betaine in middle-aged and elderly men and women. Am J Clin Nutr. 2008; 88:1663-9. [PubMed: 19064529]

[63]. Jensen HH, Batres-Marquez SP, Carriquiry A, Schalinske KL. Choline in the diets of the U.S. population: NHANES, 2003-2004. FASEB J. 2007; 21:1b219.

[64]. Fischer LM, daCosta K, Kwock L, Stewart P, Lu T-S, Stabler S, et al. Sex and menopausal status influence human dietary requirements for the nutrient choline. Am J Clin Nutr. 2007; 85:127585. [PubMed: 17490963]

[65]. Resseguie ME, da Costa KA, Galanko JA, Patel M, Davis IJ, Zeisel SH. Aberrant estrogen regulation of PEMT results in choline deficiency-associated liver dysfunction. J Biol Chem. 2011; 286:1649-58. [PubMed: 21059658]

[66]. da Costa KA, Kozyreva OG, Song J, Galanko JA, Fischer LM, Zeisel SH. Common genetic polymorphisms affect the human requirement for the nutrient choline. Faseb J. 2006; 20:133644. [PubMed: 16816108]

[67]. Kohlmeier M, da Costa KA, Fischer LM, Zeisel SH. Genetic variation of folate-mediated onecarbon transfer pathway predicts susceptibility to choline deficiency in humans. Proc Natl Acad Sci U S A. 2005; 102:16025-30. [PubMed: 16236726]

[68]. McMahon KE, Farrell PM. Measurement of free choline concentrations in maternal and neonatal blood by micropyrolysis gas chromatography. Clin Chim Acta. 1985; 149:1-12. [PubMed: 4028430]

[69]. Zeisel SH, Mar M-H, Zhou Z-W, da Costa K-A. Pregnancy and lactation are associated with diminished concentrations of choline and its metabolites in rat liver. J Nutr. 1995; 125:3049-54. [PubMed: 7500183]

[70]. Sweiry JH, Page KR, Dacke CG, Abramovich DR, Yudilevich DL. Evidence of saturable uptake mechanisms at maternal and fetal sides of the perfused human placenta by rapid paired-tracer dilution: studies with calcium and choline. J Devel Physiol. 1986; 8:435-45. [PubMed: 3559059]

[71]. Ozarda Ilcol Y, Uncu G, Ulus IH. Free and phospholipid-bound choline concentrations in serum during pregnancy, after delivery and in newborns. Arch Physiol Biochem. 2002; 110:393-9. [PubMed: 12530624]

[72]. Chao CK, Pomfret EA, Zeisel SH. Uptake of choline by rat mammary-gland epithelial cells. Biochem J. 1988; 254:33-8. [PubMed: 3178755]

[73]. Holmes-McNary M, Cheng WL, Mar MH, Fussell S, Zeisel SH. Choline and choline esters in human and rat milk and infant formulas. Am J Clin Nutr. 1996; 64:572-6. [PubMed: 8839502] 
[74]. Zeisel SH, Char D, Sheard NF. Choline, phosphatidylcholine and sphingomyelin in human and bovine milk and infant formulas. J Nutr. 1986; 116:50-8. [PubMed: 3944656]

[75]. Yang EK, Blusztajn JK, Pomfret EA, Zeisel SH. Rat and human mammary tissue can synthesize choline moiety via the methylation of phosphatidylethanolamine. Biochem J. 1988; 256:821-8. [PubMed: 3223955]

[76]. Ilcol YO, Ozbek R, Hamurtekin E, Ulus IH. Choline status in newborns, infants, children, breastfeeding women, breast-fed infants and human breast milk. J Nutr Biochem. 2005; 16:489-99. [PubMed: 16043031]

[77]. Zeisel SH, Epstein MF, Wurtman RJ. Elevated choline concentration in neonatal plasma. Life Sci. 1980; 26:1827-31. [PubMed: 7392816]

[78]. Zeisel SH, Wurtman RJ. Developmental changes in rat blood choline concentration. Biochem J. 1981; 198:565-70. [PubMed: 7034731]

[79]. Shaw GM, Schaffer D, Velie EM, Morland K, Harris JA. Periconceptional vitamin use, dietary folate, and the occurrence of neural tube defects. Epidemiology. 1995; 6:219-26. [PubMed: 7619926]

[80]. Daly L, Kirke P, Molloy A, Weir D, Scott J. Folate levels and neural tube defects. Implications for prevention. JAMA. 1995; 274:1698-702. [PubMed: 7474275]

[81]. Fisher MC, Zeisel SH, Mar MH, Sadler TW. Inhibitors of choline uptake and metabolism cause developmental abnormalities in neurulating mouse embryos. Teratology. 2001; 64:114-22. [PubMed: 11460263]

[82]. Fisher MC, Zeisel SH, Mar MH, Sadler TW. Perturbations in choline metabolism cause neural tube defects in mouse embryos in vitro. Faseb J. 2002; 16:619-21. [PubMed: 11919173]

[83]. Shaw GM, Carmichael SL, Laurent C, Rasmussen SA. Maternal nutrient intakes and risk of orofacial clefts. Epidemiology. 2006; 17:285-91. [PubMed: 16570024]

[84]. Shaw GM, Finnell RH, Blom HJ, Carmichael SL, Vollset SE, Yang W, et al. Choline and risk of neural tube defects in a folate-fortified population. Epidemiology. 2009; 20:714-9. [PubMed: 19593156]

[85]. Shaw GM, Finnell RH, Blom HJ, Carmichael SL, Vollset SE, Yang W, et al. Choline and Risk of Neural Tube Defects in a Folate-Fortified Population. Epidemiology. 2009 epub:10.1097/EDE. 0b013e3181ac9fe7. 


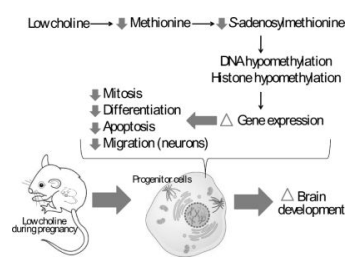

Figure 1. Choline modulates progenitor cells

In rodent models, maternal diets low in choline during pregnancy decrease methionine and $\mathrm{S}$-adenosylmethionine concentrations. This results in hypomethylation of DNA and histones that changes expression of genes regulating brain progenitor cell proliferation, differentiation, apoptosis and migration. These mechanisms may explain how maternal dietary choline influences brain function in her offspring. 